\title{
The Determinants of International Acquisition Performance in Korea : The Impact of Knowledge Transfer and Organizations' Cultural Differences and Strategic Fit
}

Joohan Ryoo(Hanyang University)

\begin{abstract}
Existing understanding of how and when knowledge is best transferred for the benefit of foreign firm's acquisition is rather limited. This study explores to what extent foreign firms have benefited from the acquisition of Korean firms and what the conditions are for such benefits. More specifically, the focus of the study is to investigate the role of knowledge transfer and inter-organizational differences in organizational culture and strategic fit on the international acquisition performance. Drawing on the literature from a knowledge based perspective, this study conceptualized the variables of international acquisition performance, knowledge transfer, differences in national and corporate culture, and strategic fit - each of which are assumed to be critical to the research question at hand - as measurement items to test seven hypotheses. After establishing 104 appropriated cases of foreign firms acquiring Korean firms during 2008 and 2010, we distributed questionnaire survey to the sample firms to test our hypotheses test. A total of 84 firms replied to the questionnaire, on which the seven hypotheses were tested. The results of the analysis revealed that knowledge transfer and compatibility in organizational culture and strategy delivered positively influenced international acquisition performance. Additionally, the positive impact of knowledge transfer is found to be enhanced when the acquiring and acquired firms are more similar in organizational culture and stronger in strategic fit. Unlike previous studies, national differences between acquiring and acquired firms did not play any direct and moderating role in the international performance. The conclusion of this study was that foreign firms intending to acquiring Korean firms should put knowledge transfer at their strategic priority and create favorable inter-organizational conditions to increase the chance of acquisition success. This study also demonstrated that knowledge transfer activities increase with
\end{abstract}

- Received: March 26, 2017 Accepted: November 26, 2017

* This work was supported by the National Research Foundation of Korea Grant funded by the Korean Government (NRF-2010-332-201000000000824).
Revised: (1st July 28, 2017; 2nd November 10, 2017)

Published: November 30, 2017 
strategic and organizational fit are more important than national difference. If managers from recently developed countries want to facilitate positive outcomes for their future international collaborations, they should determine how they can narrow the gap in corporate and social differences. As a suggestion, a gradual experience with potential partners through contract agreements prior to choosing an acquisition opposition would be helpful. Finally, this study contributed to propose the integrated framework that comprehensively examines the interrelations of critical factors. Limitation and further steps of the study are also suggested.

Keywords: International Acquisition Performance, Knowledge Transfer, Difference in Organizational Culture, National Difference, Strategic Fit
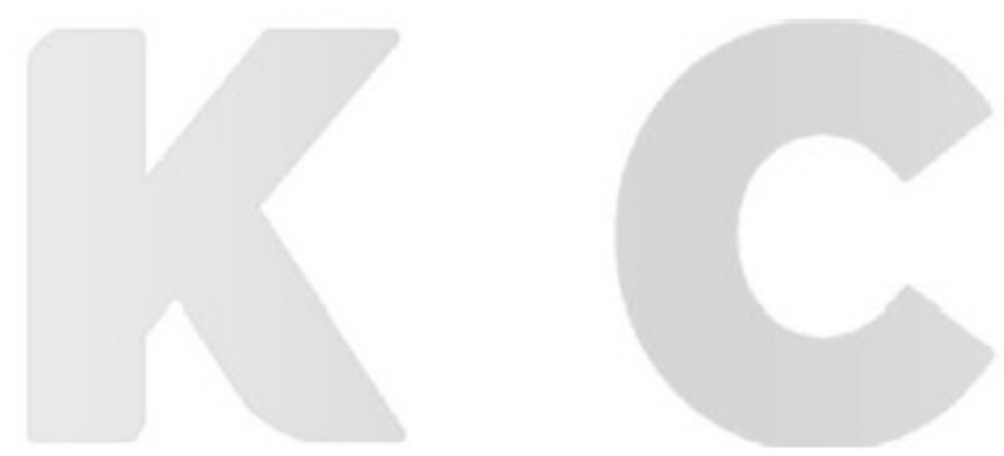


\section{해외기업의 국내기업 인수시 성과 결정요인 분석 \\ : 지식이전, 조직의 문화적 특성, 전략적 적합성을 중심으로*}

류주한(한양대학교 국제학부)

\section{요약}

본 연구는 외국기업의 우리기업 인수 후 성과에 영향을 미치는 요소가 무엇인지를 규명하는 데 목적을 두고 있다. 그동안 인수 후 성과에 관한 많은 연구가 진행되어 왔으나 외국기업이 우리기업을 인수한 사례를 대상으로 한 연구는 거의 전무한 실정이었다. 시장이 글로벌화 되고 신흥 선진국의 성장이 가속화됨에 따라 우리기업을 인수하고자 하는 해외기업이 늘고 있다. 본 연구를 토대로 그 성패요소를 규명하여 향후 진행될 유사한 사례에 이론적 실무적 시사점을 제공하는 데 목적을 두었다. 이에 본 연구는 관련 문헌을 토대로 지식이전, 국가적 차이, 기업문화적 차이, 전략적 적합성이 해외기업의 우리기업 인수 시 핵심성공요소임을 도출하였고 이들 요소의 상호작용이 인수 후 성과에 어떤 영향을 미치는지 검증하였다. 동시에 인수-피인수 기업간 국가적, 기업문화적, 전략적 차이가 지식이전과 인수 후 성과에 어떠한 조절효과로 작용하는지를 검증하였다. 가설검증을 위해 지난 2008년부터 2010년간 진행되었던 104 건의 외국기업의 국내기업 인수사례를 연구대상으로 하여 설문조사를 하였고 이중 84 개 해당기업을 분석에 사용하였다. 분석결과, 해외기업 국내기업 인수시 지식이전, 기업문화적 차이, 전략적 적합성은 인수 후 성과에 유의한 영향을 미치는 것으로 판명되었다. 한편, 인수-피인수기업 간 기업문화적 차이가 작고, 전략적 적합성이 높을수록 지식이전이 인수성과에 미치는 긍정적 효과 역시 증가하는 것으로 판명되었다. 국가적 차이는 인수 후 성과에 유의미한 영향을 미치지 않았으며 지식이전과 인수성과의 조절효과로도 작용하지 않았다. 본 연구결과를 토대로 향후 한국기업을 인수하고자 하는 외국기업은 지식이전을 인수의 최우선 목표로 삼고 인수와 통합작업을 추진할 경우 성공 가능성이 한층 높아진다는 시사점을 도출하였다. 이를 위해 인수-피인수 기업간 지식이전을 원활히 할 수 있는 기업환경을 조성하는 데 초점을 두고 전략적, 기업문화적으로 부합하는 파트너를 물색해야 하며 관련하여 무엇을 고려해야하는지를 시사점의 하나로 제공하였다. 연구의 한계와 후속 연구의 필요성도 아울러 제공하였다.

주제어: 해외기업 인수, 국가적 차이, 기업문화적 차이, 전략적 적합도, 인수후 통합

· 접수일(2017. 3. 26), 수정일(1차 2017. 7. 28; 2차 2017. 11. 10), 게재확정일(2017. 11. 26), 게재일(2017. 11. 30)

* 이 논문은 2010년도 정부재원(교육과학기술부 인문사회연구역량강화사업비)으로 연구재단의 지원을 받아 연구되었음(NRF-2010-332-201000000000824)

본 논문의 심사과정에서 유익한 조언을 해주신 익명의 세 분의 심사위원님께 감사드립니다. 


\section{Introduction}

The goal of this study is to identify to what extent foreign firms have been benefited from the acquisition of Korean firms and what the conditions are for such benefits. Firms must acquire and transfer knowledge to develop new applications and to survive (Henderson \& Cockburn, 1994; Kogut \& Zander, 1992; Wijk, Jansen, \& Lyles, 2008). Evidence has accumulated that knowledge transfer via inter-firm relationship, such as acquisitions, provides competitive advantages (Gupta \& Govindarajan, 2000; Wijk et al., 2008). Consequently, knowledge transfer across firms has emerged as an underlying theme in many studies of mergers and acquisitions. Research has identified the antecedents and consequences of knowledge transfer. For instance, researchers have inves ${ }^{-}$ tigated the role of knowledge characteristics (Armstrong \& Mahmud, 2008), organizational characteristics (Bjorkman, Stahl, \& Vaara, 2007), trust or distance with the partners and mechanisms of expediting knowledge transfer between acquiring and acquired firms (Wijk et al., 2008). At the dyad- or network-level with partners, studies have also outlined the role of social community (Bresman, Birkinshaw, \& Nobel, 2010) and of culture and socialization as a learning strategy (Zander \& Zander, 2010).

However, existing understandings of how and when knowledge is best transferred for the benefit of international acquisitions is rather limited. For instance, studies have resulted in inconsistent findings on the impact of organizations' nationality and corporate cultural differences on international acquisition (Akanni \& Ahammad, 2015; Ahammad \& Glaister, 2009; Birkinshaw, Bresman, \& Nobel, 2010; Perez-Nordtvedt, Kedia, Datta, \& Rasheed, 2008). Numerous empirical studies have also revealed that organizational differences in nationality and corporate culture have a negative effect on international $\mathrm{ac}^{-}$ quisition performance, while other studies have shown quite the opposite or have had mixed results (Ahammad, Tarba, \& Glaister, 2016; Sarala \& Vaara, 2010; Slangen, 2006; Vaara, Sarala, Stahl, \& Bjorkman, 2012).

Given the aforementioned limitations, the purpose of this study is to diagnose the role of knowledge transfer in international acquisition and to illuminate the impact of inter-organizational differences in nationality, corporate culture, and strategic fit on the performance of international acquisition. Moreover, the purpose of this study is to delineate the determinants that promote or hinder knowledge transfer effects in international acquisition. Using cases in which foreign firms acquire Korean firms is pertinent to examine the research questions in many respects. Above all, most international knowledge acquisition studies have targeted cases of firms in third world countries acquiring firms in triad countries (mostly the US and EU) to examine the effectiveness of learning and transferring knowledge (Datta \& Puia, 1995; Hitt, Harrison, Ireland \& Best, 1998; Evangelista \& Hau, 2009). Relatively little attention has been given to oth- 
er types of cases.

Recently, many global firms in the US and EU have acquired firms in third world countries for their global expansion and resource access (Lyles \& Salk, 2007; Park, Giroud, \& Glaister, 2009). However, we lack sufficient data on whether existing knowledge transfer studies would be applied in such cases in an equivalent manner; if not, what would be the appropriate conditions for knowledge transfer? Targeting foreign firms acquiring Korean firms offers numerous advantages. Korea is one of the emerging developed countries that is advanced in high-tech, manufacturing, and materials. Despite cultural and geographic distances and a lack of previous collaboration with Korean firms, many foreign firms, mostly from the US and EU, increasingly attempt to acquire Korean partners to transfer necessary knowledge and managerial skill to. Unfortunately, no previous studies have $\mathrm{ex}^{-}$ amined these in terms of their efficacy of successful knowledge transfer. By conducting this study, we can expand the validity of current knowledge about transfer from multi-national perspectives.

This study is structured in the following way: section 2 starts with a review of the relevant literature on knowledge transfer, the performance of international acquisition, and the direct and moderating impacts of differences in partners' nationalities and corporate cultures. Relevant hypotheses will be also proposed in this section. The research method and data collection procedure are described in section 3. Section 4 provides findings, followed by a discussion and conclusion in $\mathrm{sec}^{-}$ tions 5 and 6 , respectively.

\section{Literature Review and Hypotheses}

\subsection{Knowledge Transfer in International Acquisition}

International acquisition is arguably one of the most widely used competitive strategies among firms (Wikj et al., 2008). It is widely acclaimed as a way for firms to gain access to innovative capabilities, reduce the risks of new product/service development, and bring in new knowledge to enhance long-term survival (Vasilaki \& O'Regan, 2008). Recently international acquisition has been increasingly popular in transferring knowledge across borders (Hayward, 2002; Wu, 2016). The knowledge base of recipients may be enhanced via the transfer of critically significant knowledge by which the recipients can accumulate the skills and expertise that allow them to perform smoothly and efficiently (Wikj et al., 2008; Kogut \& Zander, 1992; Brement et al., 2010)(See appendix 1 for literature summary).

In international acquisition contexts, knowledge transfer refers to the process through which organizational actors exchange, receive, and are influenced by the experiences and knowledge of others (Wilkj, et al., 2008). Knowledge may be transferred in either or both 
from acquiring to acquired unit or from acquired to acquiring unit, indicating that it is a reciprocal and cross-transferring effort for potential value creation (Wilkj, et al., 2010; Bremen et al., 2010). Indeed, both acquiring and acquired firms are recipients of substantial devotion of each other's essential resources.

As one of the fundamental goals of international acquisition, knowledge transfer plays an important role in realizing value creation and capturing synergy from partnering firms (Perez-Nordvedt et al., 2008; Ranft \& Lord, 2002; Wijk et al., 2008). Because of the significant role of knowledge transfer in value creation, research has investigated what facilitates or hinders value creation resulting from knowledge transfer in international acquisitions. Researchers on this issue have paid attention to the impact of organizational factors such as organizational culture and previous learning experience to show their contribution on knowledge transfer (Wu, 2016). Organizational size and age have been also deemed as important determinants of knowledge transfer where relatively young but large firms are supposed to be more easily modified and adaptable in the changing environment of knowledge transfer (Frost, Birkinshaw, \& Ensign, 2002; Gupta \& Govindarajan, 2000; Laursen \& Salter, 2006; Wikj et al., 2008).

Furthermore, absorptive capacity and organizational climate are documented $\mathrm{ex}^{-}$ tensively as key determinants (Hammami, Amara, \& Landry, 2013; Wikj et al., 2008).
Absorptive capacity indicates an ability of a firm to recognize, assimilate, and apply new external knowledge, facilitating organizational knowledge transfer and learning across partnering firms (Cohen \& Levinthal, 1990; Gupta \& Govindarajan, 2000; Mowery, Oxley, \& Silverman, 1996). Organizational climate re- $^{-}$ fers to employees' shared perceptions of behavioral types and actions (Hammami et al., 2013; Schneider, Salvaggio, \& Subirats, 2002). Organizational climate is thought to exert a considerable influence in increasing, encouraging, generating, sharing, applying new knowledge, and members' participation (Hammami et al., 2013). In this vein, both absorptive capacity and organizational climate explain knowledge transfer performed by international acquisition.

The recent trend in acquisition studies has been to view knowledge transfer as a communication process that involves actively exchanging knowledge at the level of the individual, group, product, or division in the most effective manners (Pérez-Nordtvedt et al., 2008; Shan, Walker \& Kogut, 1994). This view concerns the collaboration of the source (sender) and receiver and contextual issues surrounding the communications process (Perez-Nordtvedt et al., 2008). What are important in the collaboration process are the identification of the sources, the willingness of sources to share knowledge, the willingness of receivers' knowledge acquisition, and the absorptive capacity of the receiver (Easterby-Smith, Lyles, \& Tsang, 2008; Zou \& Ghauri, 2008). In this process view, 
the nature of transferred knowledge is critical for the success of international acquisition (Evangelista \& Hau, 2007). Transferred knowledge such as patents, physical distribution methods, and promotion techniques may be easily learned by rivals and disseminated around the world (Evangelista \& Hau, 2007). However, intangible knowledge such as relational skills and partners' experiences, which are accumulated by interfirm relationship processes, may not be easily migrated to others. The advantage of intentional acquisition is that the acquiring firms can acquire various types of implicit knowledge from overseas markets more effectively and efficiently.

According to the knowledge-based view, a firm's ability to create and transfer knowledge depends mostly on sets of intangible or tacit knowledge resources (Nonaka, 1994). Firms can realize an above-average performance if they create idiosyncratic and non-substitutable knowledge that can be used for added value. Creating and transferring such knowledge by virtue of international acquisition would be a daunting task, as we have witnessed many problems and costs. Nevertheless, it is widely acknowledged that acquiring intangible or tacit knowledge can be accessed efficiently and directly through an international acquisition that allows the grafting of the implicit knowledge of one firm onto another firm's implicit knowledge (Ahammad et al., 2016). Such acquired knowledge ultimately contributes to the improvement of the competitive edge of the acquiring firm.
Many studies have identified that intangible or tacit knowledge is established in individual experience, and it is procedural rather than explicative or instructive in structure (Ahammad et al., 2016). Although such types of knowledge are difficult to codify and transmit because of their experiential nature, several studies have revealed that acquisition is more efficient as a type of organizational structure in transferring implicit knowledge than any others (Armstrong \& Mahmud, 2008). In international acquisition, both $\mathrm{ac}^{-}$ quiring and acquired firms can create social interactions by creating a venue for channeling tacit knowledge by collective tasks and joint efforts (Armstrong \& Mahmud, 2008; Vaara et al., 2012; Zander \& Zander, 2010). Extending these, this study demonstrates that transferring and exchanging tacit knowledge are more probable in international acquisition compared to other alternative governance modes because of the close interaction among partnering firms. Thus, the positive effects of knowledge transfer are typical in international acquisition.

H1: Knowledge transfer delivers a positive impact on the performance of international acquisition.

\subsection{Difference in Organizational Culture}

Organizational culture implies a firm's routines, managerial styles, and communications systems. Datta and Puia (1995) contend that 
differences in organizational culture retard the transfer of key functional knowledge such as technology, marketing, and management know-how (Park et al., 2009). Dissimilarity in organizational culture increases psychic distance, which readily engenders conflict between organizational members (Hennart \& Larimo, 1998; Park et al., 2009). This becomes a source of perceived higher transaction costs among organizational members, resulting in the deterioration of organizational performance. This obviously affects the learning activities of organizational members negatively.

Differences in organizational culture between acquiring and acquired firms are very problematic (Weber, Shenkar, \& Raveh, 1996; Weber, Tarba, \& Rozen-Barchar, 2012). Divergent corporate cultures in management style and cultural gaps in terms of human resource factors would delay even the effective post-merger integration process, which increases the complexity of the synergy of the combined firms (Weber et al., 2012). Moreover, the organizations' cultural differences increase conflict between the combined firms, leading to an inferior result for the international acquisition (Sarala, 2010; Sarala \& Vaara, 2010). This is why various cultural integration mechanisms such as communication, the use of expatriates, and integration teams are effective tools to overcome the cultural differences of the combined firms (Datta \& Puia, 1995).

Indeed, cultural differences in international acquisition are a predictor for determining the success or failure of mutual cooperation. Low cultural compatibility ensures the negative outcome of intra-national acquisition. Employees from different cultures are so enthralled with their own corporate cultures that cooperating with other culturally dissimilar partners may result in serious problems that hamper smooth knowledge exchange, commitment, and the satisfaction of the acquiring firm. Thus, in this study, the following hypothesis is proposed:

H2(a): Differences in organizational culture between acquiring and acquired firms will have a negative impact on the performance of international acquisition.

Moreover, increase in organizational cultural difference would slow the smooth process of knowledge transfer between acquired and acquiring firms, diminishing positive knowledge transfer impact. That is because dissimilarity in communication and management style in divergent organizational culture increases the transaction cost of knowledge flow. Thus, this study proposes:

H2(b): Increases in organizational cultural differences between them weaken the positive relationship between knowledge transfer and the performance of international acquisition. 


\subsection{Difference in National Culture}

Hofstede's (1980) framework of national culture value has been widely used in international management studies. However, the relationship between the difference in national culture and the performance of international acquisition is unclear(See appendix 2 for literature summary). The positive view demonstrates that acquisition will improve its performance in the long term if merging firms are from different nationalities, especially when they are more disparate in national culture (Morosini, Shane, \& Singh, 1998; Vermeulen \& Barkeman, 2001; Ahammad et al., 2016). The key to the positive view is that specific knowledge stocks that are embedded in different national culture would advance more in different national institutions (Sarala \& Vaara, 2010; Slangen, 2006). International acquisitions formed in culturally distant countries increase the likelihood of creating different routines and repertoires, which grows to be different knowledge stocks (Sarala \& Vaara, 2010). Researchers explain that different knowledge stocks are likely to be less duplicative and more complementary for acquiring firms, helping to create knowledge transfer potential and organizational competences (Bjorkman et al., 2007; Sarala \& Vaara, 2010; Shenkar, 2001). Thus, difference in national culture contributes to increased knowledge transfer between the acquiring and acquired firms.

Contrarily, the opposite view contends that differences in national culture would deter the understandability of the acquired firm's core competencies that must be transferred (Reus \& Lamont, 2009). According to this view, distance in national culture would limit communications between acquired and acquiring firms negatively regarding the acquisition performance (Ahammad et al., 2016; Olie, 1994; Teerikangas \& Very, 2006). Distance in national culture would also render the implementation of preplanned integration plans less effective and reduce the extent to which acquirers can learn from acquired a firm's experiences and implicit know-how abroad (Slangen, 2006; Uhlenbruck, 2004).

The negative view suggests that differences in national culture cause fundamental integration problems associated with identity differences (Olie, 1994; Vaara, 2003; Weber et al., 1996). These differences often lead to nationalistic confrontation, politicization, and stickiness of knowledge, hampering knowledge transfer in international acquisition (Vaara, 2003; Szulanski, 1996). These arguments suggest that the differences in national culture do deteriorate the performance of $\mathrm{ac}^{-}$ quiring firms. Thus, in this study, the following hypothesis is proposed:

H3(a): Differences in national culture between acquiring and acquired firms will have a negative impact on the performance of international acquisition.

In addition, national cultural differences 
weaken positive relationships between knowledge transfer and international performance. Several studies reveal that the success rate of international acquisition is quite lower than that of domestic acquisition due to the difficulties of transmitting essential knowledge across the nations. Therefore, this study proposes:

H3(b): Increases in differences in national culture between them weaken the positive relationship between knowledge transfer and the performance of international acquisition.

\subsection{The strategic Fit Between Acquired and Acquiring Firms}

The strategic fit between acquiring and acquired firms is crucial for creating synergies in international acquisitions. Strategic fit indicates whether overall strategic objectives such as market expansion, vertical integration, and new market/product entry can be coordinated and arranged well between acquiring and acquired firms (Child, Falkner, \& Pitkethly, 2001). The extent of the alignment in strategic objectives determines post-acquisition performance.

This study particularly concerns strategic fit in terms of mutual understandings of strategic priorities, objectives, and strategic opportunity identification (Aguilera \& Dencker, 2004). Assessing strategic fit is significant in international acquisition because it is related to the preservation and retention of the key employees of the acquired firms during the post-acquisition period (Aguilera \& Denker, 2004). It is reported that about $75 \%$ of the top managers tend to leave acquiring firms during the third year after acquisition, and more $\mathrm{se}^{-}$ nior managers in the acquired firms tend to leave the organization than those in non-acquired ones (Krug, Wright, \& Kroll, 2014; Weber et al., 2012). It is also well documented that strategic misfit results in misfit in HR training, development, appraisal, and reward systems which may also cause tremendous post-acquisition backlashes among the amalgamated entities (Krug et al., 2014).

Retaining key employees of the acquired firm is key to the success of international acquisition, as it is largely dependent on successfully leveraging skills, experience, and knowledge presented in the human resources of the acquired firm (Ahammad et al., 2016). Dissimilar strategic goals and practices are attributed as the major reasons of high turnover rates in acquired firms (Walsh, 1988). Since there exists no best practice for strategic international acquisition, acquiring firms should consider narrowing the strategic misfit from the beginning between the partners to avoid high turnover rates. Whereas a lack of strategic fit will be more likely to create myriad uncertainties among the existing employees involved in international acquisition, strategic fits would offer favorable condition of mutual knowledge transfer. Thus, this study proposes: 
H4(a): Lack of strategic fit between acquiring and acquired firms will have a negative impact on the performance of international acquisition.

Furthermore, a strategic gap between partnering firms would hamper the positive impact of knowledge transfer on the acquisition engaged firms. The dissimilarity of the strategic goals and the high likelihood of turnover rate of main employees render knowledge transfer process rather slow and efficient, leading to the less than expected acquisition outcome. Thus, this study proposes:

H4(b): increases in the strategic gap between them weaken the relationship between knowledge transfer and performance of international acquisition.

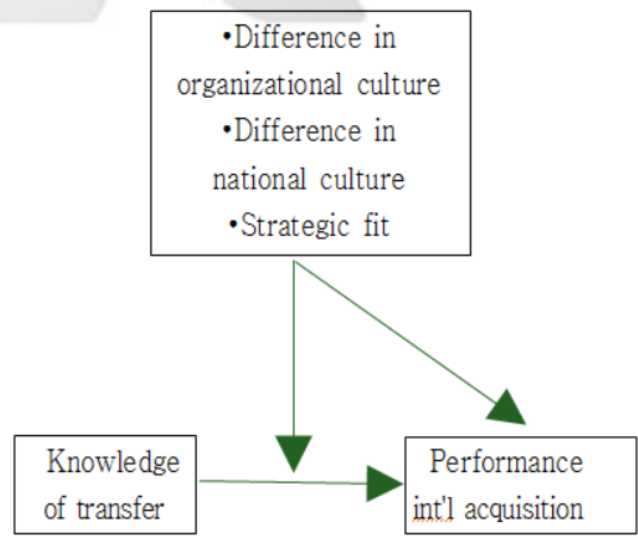

Figure 1. Illustrates Research Framework of this Study.

\section{Methodology}

\subsection{Sample and Data Collection}

For this study, a questionnaire survey method was used to collect data from foreign multinational firms that acquired Korean firms during the three years of 2008-2010, and it is sufficient at this point in time to measure the acquisition outcome. Potential sample lists were collected from the ZYPHYR database, which contains 1,325 related reported cases during the same years. Among them, relatively small deals (those the amount of $\$ 1$ million)-those involving the acquisition of subsidiaries, the expansion of existing ownership, acquisitions in banking industry, acquisition by financial investors, and investment of less than $30 \%$ of equity ownership-were excluded from this study. For this study, these were not considered as knowledge transfer associated with acquisitions. Additionally, for the convenience of analysis, the focus of this study was acquisition in related business areas. Based on a strict sample selection criteria, knowledge-transfer associated international acquisition towards Korean firms was extracted for this study from the database by reviewing the goal of acquisitions such as getting access to local market knowledge and acquiring managerial skills, human resources, and marketing and manufacturing know-how.

A total of 104 cases were found suitable for this study. Most of the acquiring firms are from developed countries in Western Europe, 
North America, Japan, and Australia, and some are from emerging countries in Asia and the Middle East. The relevant cases encompass companies mostly in manufacturing oil, water, cement, chemical, electronic components, fabrics, and automobiles and some from advertising and IT sectors (Table 1).

\section{Table 1}

Description of Sample Firms $(\mathrm{N}=84)$

\begin{tabular}{|c|c|}
\hline \multicolumn{2}{|l|}{ Industry type } \\
\hline Manufacturing & 24 \\
\hline Construction & 5 \\
\hline \multicolumn{2}{|l|}{ Chemical/Material } \\
\hline Energy & 2 \\
\hline Medical/Bio/R\&D & 4 \\
\hline IT & 15 \\
\hline Retai & 2 \\
\hline Etc & 20 \\
\hline \multicolumn{2}{|c|}{ Nationality of acquiring firm } \\
\hline EU & 31 \\
\hline N. America & 24 \\
\hline Japan & 13 \\
\hline Asia & 13 \\
\hline Etc. & 3 \\
\hline \multicolumn{2}{|c|}{ Deal size of acquisition (USD Thous) } \\
\hline $1,000-5,000$ & 15 \\
\hline $5,001-50,000$ & 49 \\
\hline $50,001-100,000$ & 13 \\
\hline $100,001-500,000$ & 23 \\
\hline more than 500,001 & \\
\hline \multicolumn{2}{|l|}{ Employees (no.) } \\
\hline Less than 100 & 0 \\
\hline $101-500$ & 24 \\
\hline $501-1,000$ & 36 \\
\hline More than 1,000 & 24 \\
\hline
\end{tabular}

Reviewing the description of these acquisitions revealed that the acquisitions were motivated to initiate interaction with Korean partners for transferring local knowledge and skills for enhancing the core competences. The questionnaire was distributed to the heads of strategic planning departments from March 15, 2016, to May 16, 2016. The participants were guaranteed of their anonymity, and two or three reminder messages were sent to encourage the participation in the survey. In order to reduce the common method bias, we intentionally distributed the questionnaire at different point of time. After $\mathrm{ex}^{-}$ cluding 20 questionnaires because their information was incomplete, a total of $84 \mathrm{com}^{-}$ pleted questionnaires from responding firms were collected, which resulted an $80.7 \% \mathrm{re}^{-}$ sponse rate. Response bias was tested by comparing company size, industry type, and profitability between (a) early and late $\mathrm{re}^{-}$ spondents, (b) anonymous and identified $\mathrm{re}^{-}$ spondents, and (c) respondents and nonrespondents. We found no serious response bias.

\subsection{Measurement of Variables}

Drawing on Schoenberg (2004), Ahammad et al. (2016), and Sousa and Tan (2010), the performance of international acquisition was measured in terms of the extent to which the expected performance of acquiring firms are met in terms of sales revenue, profitability, market share, and overall performance im- 
provement (a total of four items). A seven-point Likert scale was used to measure these constructs. Responses ranged from " $1=$ expectation not met" to " $7=$ expectation fully me" considering performance three years after a deal is made.

Knowledge transfer indicates the extent to which the respondents have exchanged, $\mathrm{ac}^{-}$ quired, or learned market knowledge (foreign culture and taste), customer information, operational processes, and research and development (Anh, Bughn, Hang, \& Neupert, 2006; Lyles \& Salk, 2007). Four items were developed and measured using a seven-point scale (1="not at all," and 7="very much").

Difference in organizational culture indicates the gap in organization-specific beliefs, values, and practice between acquiring and acquired firms (Sarala \& Vaara, 2010). Instead of measuring it using objective items such as mission statements and reward systems, the measurements of Chatterjee, Lubatkin, Schweiger and Weber (1992) and Sarala and Vaara (2010) were adopted and modified for this study. Using a seven-point Likert scale (1="no differences," and 7="significant differences"), the $\mathrm{re}^{-}$ spondents were directly asked about their opinions of cultural gaps with the acquired firms in terms of management/control, sales/marketing, production, R\&D, finance, and corporate value as well as for their overall opinions (three items). Borrowing and modifying the approaches of Evangelista and Hau (2009) and Simonin (1999) and Lyles et al. (1999), this study used three items to measure the difference in national culture between acquiring and acquired firms, where 1 indicates "no differences" and 7 indicates "significant differences." The respondents were asked to what extent the two countries differ from each other in terms of national culture and communication style. Additionally, they were asked if such national cultural difference had been the source of organizational problems and misunderstandings in process of post-acquisition integration.

Strategic fit refers to the mutual understanding priority, roles, objectives, and strategic opportunity identification (Sousa \& Tan, 2015). Using a seven-point Likert scale, where 1 denotes "no fit at all" and 7 denotes "significant fit," five items were measured as strategic fits between acquiring and acquired firms. The items were reverse--coded at the analysis.

Relative size, previous experience of international cooperation, and industry type were used in this study as control variables. Relative size was measured to rate the relative revenue of acquired and acquiring firms before the international acquisition. A five-point Likert scale was used, with re- $^{-}$ sponses ranging from 1 (acquired firms were far smaller in revenue) to 5 (acquired firms were far larger in revenue). Previous experience indicates to what extent the respondents experienced the acquisition or interfirm partnership on a seven-point Likert scale ranging from 1="no experience" to 7="great experience" (more than 20 times) (Ahammad et al., 2016). Industry type is classified into dichoto- 
mous types (e.g., manufacturing vs. service/R\&D industry) for the convenience of the analysis.

Cronbach's a was used to approve the reliability of the construct items $(a>0.6$; Nunnally 1978). Factor analysis was used to decide whether questionnaire items measured concepts correctly. This study used the principle component analysis with Varimax rotation to examine whether independent and moderating variables measured single concepts of interest appropriately. Hierarchical regression analysis (SPSS ver. 18; SPSS Inc., Chicago, IL, USA) was used to examine the impact of independent and the moderating variables on acquisition performance.

Model 1 encompassed the control variable only, model 2 added independent variables, and model 3 added interaction effects of distance of organizational and national culture and strategic fit to the relationship between knowledge transfer and its subsequent performance. Hierarchical regression coefficients represent the mean change in the response variable for one unit of change in the predictor variable while holding other predictors in the model constant. The statistical control that regression provides is important because it isolates the role of one variables from all of the others in the model.

\section{Findings}

Descriptive statistics indicate that the re- spondents were representative with a wide range of variation and no significant response bias (Table 1). Each of the Cronbach's a values for the entire scale exceeded 0.6, indicating internal consistency and reliability (Churchill Jr., 1979). Factor analysis was used to examine the validity of all instrument items (Table 2). The principal component analysis created single components with eigenvalue $>1$ for all variables, indicating conceptual validity. No measurement problem was detected thus, the instrument $\mathrm{de}^{-}$ veloped in this study measured the intended concepts accurately and consistently. We investigated the correlation matrix to identify any correlation matrix between the variables in our model. The correlation table in Table 3 revealed no serious collinearity problems (Hair, Anderson, Tatham, \& Black, 1998). Additionally, the value of variance inflation factor (VIF) stayed under the recommended limit of 10 for all models (Table 4).

Hierarchical regression analysis was used to the effects of independent and control variables in international acquisition performance and to distinguish between direct and interaction effect (Table 4). In Model 1, we tested the effect of control variables. In Model 2, we introduced knowledge transfer, the difference in organizational culture, difference in national culture, and the strategic fit between acquired and acquiring firms to test $\mathrm{H} 1, \mathrm{H} 2(\mathrm{a}), \mathrm{H} 3(\mathrm{a})$, and H4(a). In Model 3, we tested the interaction among H2(b), H3(b), and H4(b). All models were statistically significant and fit the data well. 
Table 2

Results of Factor Analysis and Reliability Analysis

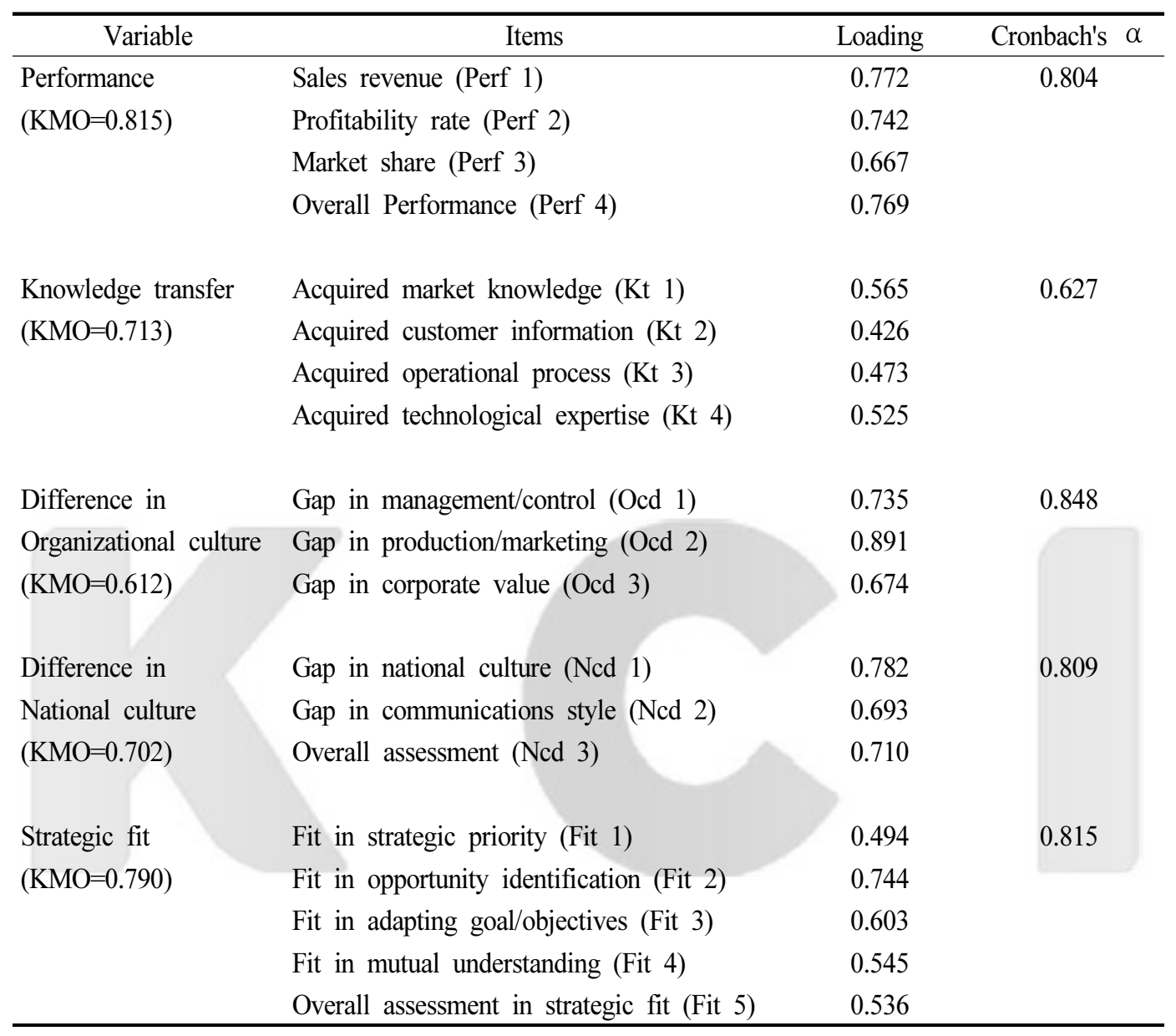

Hypothesis H1, which proposed that the degree of knowledge transfer was positively associated with the performance of international $\mathrm{ac}^{-}$ quisition, was supported in this study (Model 2, $\beta=0.519^{* *}$ ). Regarding hypothesis H2(a), our prediction that differences in organizational culture would be negatively associated by the performance of international acquisition was supported (Model 2, $\beta=-0.262^{* *}$ ). Hypothesis H3(a) - that difference in national culture would influ- ence the performance of international acquisition negatively - was not supported. Consistent with hypothesis H4(a), we would prove a lack of strategic fit between acquiring and acquired firms diminishes the performance of international acquisition (Model 2, $\beta=-0.218^{* *}$ ). Strong support was found for hypothesis H2(b)namely, that the positive association of knowledge transfer and the performance of international acquisition would be weaker as the differ- 
Table 3

Descriptive Statistics \& Correlations among Variables $(\mathrm{n}=84)$

\begin{tabular}{ccccccccccc}
\hline & Mean & SD & 1 & 2 & 3 & 4 & 5 & 6 & 7 & 8 \\
\hline 1 & 4.00 & 0.60 & 1 & & & & & & & \\
2 & 3.96 & 0.52 & $0.57^{* *}$ & 1 & & & & & & \\
3 & 3.92 & 0.74 & $-0.33^{* *}$ & $-0.32^{* *}$ & 1 & & & & & \\
4 & 3.93 & 0.63 & $-0.38^{* *}$ & $-0.27^{*}$ & $-0.42^{* *}$ & 1 & & & & \\
5 & 3.88 & 0.68 & $-0.36^{*}$ & $0.29^{* *}$ & $0.67^{* *}$ & $0.22^{* *}$ & 1 & & & \\
6 & 2.39 & 0.82 & -0.03 & 0.05 & 0.11 & -0.07 & -0.01 & 1 & & \\
7 & 4.67 & 0.79 & 0.14 & -0.02 & -0.01 & 0.16 & -0.04 & 0.06 & 1 & \\
8 & 0.58 & 0.49 & -0.10 & 0.13 & 0.03 & 0.01 & 0.07 & -0.06 & -0.16 & 1 \\
\hline
\end{tabular}

Note. SD, Standard deviation. 1(performance), 2(Knowledge transfer), 3(Difference in organizational culture), 4(Difference in national culture), 5(Organizational strategic fit), 6(Relative firm size), 7(Previous experience in international cooperation), 8 (Industry type).

${ }^{*} \mathrm{P}<0.05,{ }^{* *} \mathrm{P}<0.01$ (Two-tailed)

\section{Table 4}

Results of Hierarchical Regression Analysis

\begin{tabular}{lccc}
\hline \multicolumn{1}{c}{ Variable } & Model 1 & Model 2 & Model 3 \\
\hline \multicolumn{1}{c}{ Control variables } & & & \\
Relative firm size(SZ) & -0.051 & -0.121 & -0.115 \\
Previous experience(EXP) & 0.137 & $0.187^{* *}$ & $0.162^{* *}$ \\
Industry type(TYP) & -0.083 & -0.148 & -0.122 \\
$\quad$ Explanatory variables & & & \\
Knowledge transfer(KT) & & $0.519^{* *}$ & $2.222^{* *}$ \\
Difference in organizational culture(DOC) & & $-0.262^{* *}$ & $-2.737^{* *}$ \\
Difference in national culture(DNC) & & -0.035 & 1.113 \\
Strategic fit(FIT) & & $-0.218^{* *}$ & .411 \\
$\quad$ Interaction variables & & \\
KT $\times$ DOC & & & $-3.355^{* *}$ \\
KT $\times$ DNC & & & 1.353 \\
KT $\times$ FIT & .030 & .454 & $.0 .325^{* *}$ \\
$\mathrm{R}^{2}$ & 0.006 & .411 & .585 \\
$\mathrm{R}^{2}$ (Adjusted) & .837 & $10.673^{* *}$ & $11.568^{* *}$ \\
F(Statistics) & 1.03 & 1.08 & 1.09 \\
$\quad$ All VIFs $<10$ & & & \\
\hline
\end{tabular}

Note. VIF, Variance inflation factor

All two-tailed tests. ${ }^{*} \mathrm{P}<0.05,{ }^{* *} \mathrm{P}<0.01$

Data in the table represent standardized beta coefficients

Dependent variable: International acquisition performance 
ence in organizational culture becomes greater (Model 3, $\beta=-3.355^{* *}$ ). Hypothesis H3(b), how ${ }^{-}$ ever, was not supported, indicating that difference in national culture does not weaken the positive relationship between knowledge transfer and the performance of international acquisition. Hypothesis H4(b) - that the positive relationship between knowledge transfer and the performance of international acquisition would weaken as the gap of strategic fit between acquiring and acquired firms becomes widerwas supported (Model 3, $\beta=-0.325^{* *}$ ).

The control variables such as relative size and industry type between acquiring and $\mathrm{ac}^{-}$ quired firms were not proven significant. However, the previous experience in international acquisition was positively associated with international acquisition performance (Model 2, $\beta=0.187^{* *}$; Model 3, $\beta=0.162^{* *}$ ).

\section{Discussion}

Despite the proliferation of studies on knowledge transfer in international acquisition, we still lack a conclusive understanding of what determines successful knowledge transfer and its subsequent performance. Even worse, existing studies have delivered inconsistent and confusing findings about

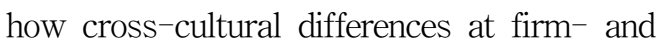
national levels have both positive and negative effects on international acquisition (Ahammad et al., 2016; Sarala \& Vaara, 2012; Slangen, 2006; Teerikangas \& Very, 2006;
Weber et al., 2012). In particular, academic studies and business reports fail to uncover recent cross-border acquisition activities of emerging countries as to their determinants of successful integration with foreign partners. Due to lack of overseas acquisition experience for knowledge transfer, many emerging market acquiring firms have suffered from the trials-and-errors of organizational knowledge combinations while some others have not relatively.

Amid academic and practical confusions, this study addresses what determines the success of international acquisition when foreign firms acquire Korean firms. Using such cases is appropriate for both academic and practical fields. First, few knowledge transfer studies have concerned the mechanism of learning in acquisition from newly developed countries such as Korea. Second, using the cases of Korean firms' knowledge acquisition is highly exceptional because these firms are at their lead in knowledge acquisition in various high-tech industries and their cross-border acquisition activities are phenomenal recently.

Drawing on the knowledge-based perspective, the dimensions of knowledge transfer, cultural dynamics, and organizational strategic compatibility are determined in this study to be crucial for understanding such inquiries (Akanni \& Ahammad, 2015; Easterby-Smith et al., 2008; Lyes \& Salk, 2007; Perez-Nordtvedt et al., 2008; Reus \& Lamond, 2009). More specifically, from the 84 cases of foreign companies 
acquiring Korean firms during 2008 to 2010, it is found in this study that the degree of knowledge transfer and similarity in organizational culture and strategic fit between acquiring and acquired firms is a critical success factor in international acquisition. Additionally, this study revealed that the positive impact of knowledge transfer would be further facilitated when two partners fit well culturally and strategically.

This study has resulted in several practical and managerial implications. First, the study specified the mechanisms that help to understand the success of international acquisition in Korea. Recently, many foreign firms intended to acquire Korean firms in order to learn the tastes of Korean customers, transfer Korean firms' manufacturing and operational knowledge, and establish local distribution channels (Park et al., 2009). However, the result of their efforts has been unclear. Some useful insights from previous studies are irrelevant because of different national and industrial contexts (Anh et al., 2006; Tsang, 2008). In this study, we argue that international managers should make the issue of knowledge transfer a primary strategic agenda to lead successful acquisitions with Korean partners, instead of issues of cost saving and efficient resource use. This finding is in line with many mergers and acquisitions studies that evince that international acquisition will not succeed unless acquiring firms establish a strong commitment and intent to transfer relevant knowledge from acquired partners
(Hamel, 1991; Hayward, 2002; Hitt et al., 1998; Inkpen \& Crossan, 1996; Zou \& Ghauri, 2008).

By the same token, Korean firms planning international acquisition should have strong commitment to transfer essential knowledge from the partners. We argue that emerging market firms should venture abroad to leverage their existing firm-specific assets by acquiring or seeking strategic assets so as to overcome latecomer disadvantages. In such ventures, Korean firms must first establish explicit commitment to learn and transfer strategic assets from the partners; otherwise, they cannot design the right linkage, leverage and learning process with the explicit goal of gaining strategic asset not available at home. In practice, designing well-planned post-merger integration and communication strategies with Korean targets will help to enhance knowledge transfer process.

Second, this study provides empirical support for the assertion that similarity in organizational culture and compatibility in strategic goals enhance international acquisition performance. This finding confirms previous studies (Datta \& Puia, 1995; Hammami, Amara, \& Landry, 2013; Vaara et al., 2012). Difference in organizational culture implies that acquiring and $\mathrm{ac}^{-}$ quired firms' norms, routines, and repertoires are dissimilar. Our finding highlights that cross-border acquisition with Korean firms performs better when organizational cultural distance is narrow. This finding is entirely different from that of cross-border acquisitions in Europe where the cultural difference has not much impeded the acquisition performance. 
When organizational culture is compatible, the two partnering firms can conveniently synthesize their inventiveness, innovation, entrepreneurship, and decision-making practices, which is essential to the acquisition success. Interview with the executives of the responding firms manifested why compatibility of the organizational culture is important in transferring organizational routines and repertoires from one partner to the others.

Interestingly, difference in national culture was not an immediate hindrance for the success of international acquisition, even when two partners are from culturally divergent contexts. This finding is quite in contrast with studies in which researchers note the significant role of national culture in international acquisition success (Slangen, 2006). We assume that the augmented international $\mathrm{ex}^{-}$ perience of Korean firms has progressively increased the cultural intelligence of other nations. Thus, cross-cultural intelligence has improved enough to adapt to different national cultures. As our findings revealed, what matters most in the success of international $\mathrm{ac}^{-}$ quisition is organizational compatibility in corporate culture and strategic fit rather than national differences. In this study, we argue that poor organizational culture and strategic fit would become serious obstacles to administrative, cultural, interpersonal, and management system integration.

In fact, companies are social groups with their own identities. If a new group (an $\mathrm{ac}^{-}$ quiring firm) is similar to another's (the $\mathrm{ac}^{-}$ quired firm), employees are likely to give up their old identities and transition into a new identity smoothly. If the new group is subsequently dissimilar, however, the employees will likely want to stay in their old identities, and the new group will be difficult to integrate into the old one. Organizational compatibility in corporate culture and strategic fit means that both acquiring and acquired firms are likely to feel more social identity with each other. This study advises that foreign firms must seek conformity in corporate culture and strategic fit with Korean partners in order to increase the chance of international acquisition success. From the Korean firm's perspective, internationationalization would be the key solution to it by forming more interfirm relationship and collaboration as they offer more chance to experience international market and other firms' cultures; expanding foreign market entry options from the international trade is essential to many Korean firms.

Third, the compatibility in organizational culture and strategic fit is not only the determinant of successful international acquisition; it is also creates favorable conditions for knowledge transfer from acquired firms. It is well-recognized that social factors such as organizational climate, trust, and employees' willingness are important for knowledge transfer. However, these are not built in a short time period, and managers should make significant efforts to construct consensus-based social mechanisms for governing knowledge 
transfer with the partners. This study demonstrated that strong cultural and strategic fitness with Korean partners would alleviate such efforts to a larger extent, as each partner is more likely to occupy socially collaborative constructs. For Korean firms, they have to note that easy communication, low internal competition, and anti-hierarchical organization are unanimously recognized as a way to form consensus-based social mechanisms for knowledge transfer with foreign partners.

The findings of this study also have theoretical implications. First, this study contributes to the theoretical development of conceptual models for explaining inter-relationships among knowledge transfer, organizations' cultural distance, strategic fit, and international acquisition performance. Despite well-proven evidence of the positive impact of knowledge transfer on international acquisition, a dearth of studies have comprehensively examined the interrelationship among them (i.e., knowledge transfer, distance in organizational culture, and strategic fit) in an integrated research model. The lack of such studies is a serious impairment in international acquisition research since various critical conditions essential to successful international knowledge transfer mechanism have been less attended. This study fills such a gap.

Second, knowledge transfer from newly developed countries has received little academic attention. New trends in research in this area suggest that foreign firms increasingly acquire firms in newly developed coun- tries (for example, Korea) for various strategic reasons. However, the underlying mechanisms of their success have been outside the research agenda because of a heavy academic focus on knowledge transfer from multinational firms among and between developed countries. In this study, a new insight is constructed about what ought to be the proper framework for building successful international acquisitions in newly developed countries.

Third, prior research address the harmonization of social constructs that is an essential conduit for enhanced acquisition performance, highlighting its critical role in knowledge transfer mechanisms (Bjorkman et al., 2007; Sarala, 2010; Shenkar, 2001). By showing the moderating role of the social factors (that is, organizational culture and strategic fit), the empirical evidence of this study fills the gap in the literature about how knowledge transfer and social construct are combined in international acquisition contexts.

Despite managerial and theoretical contributions, this study is not without limitations. First, the use of cross-sectional research design may not fully reflect the mechanisms of successful international acquisition activities in Korea. This study only relied on the $\mathrm{re}^{-}$ spondents' retrospective reconstruction of the events in a short time frame (i.e., of the recent past 3 years); observation would be too limited to triangulate reliable perspectives. Thus, $\mathrm{fu}^{-}$ ture research must address knowledge transfer and its condition issues in a longitudinal design 
that expands the time span of observation.

Second, knowledge transfer from the firms in recently developed countries has been an uncommon research agenda. Thus, in-depth qualitative research from both the sender and recipient's perspectives is essential to uncover the complete information about the identified conditions in this study. In-depth case studies would be helpful as an alternative to one-sided investigation, including both acquisition partners, who are able to $\mathrm{ex}^{-}$ press their opinions on the process of knowledge transfer and social harmonization so that possible bias and overlooking important facts can be avoided.

Third, the findings of this study are idiosyncratic to the condition of the Korean market; thus, applying them to other national contexts at various industrial sectors is necessary to generalize the findings.

\section{Conclusion}

This study offers a provisional model and its explanation based on the empirical evidences that are open to modification and reformulation. Nevertheless, this study proposes that constructing effective international acquisition toward recently developed countries can be done through a firm's engagement in actively leveraging the knowledge and experience from acquired firms by building an amicable inter-organizational social climate. This study demonstrates that knowl- edge transfer activities interacted with strategic and organizational fit are more important than national difference. However, if managers from recently developed countries want to facilitate positive outcomes for their future international collaborations, they should $\mathrm{de}^{-}$ termine how they can narrow the gap in corporate and social differences. As a suggestion, a gradual experience with potential partners through contract agreements prior to choosing an acquisition option would be helpful.
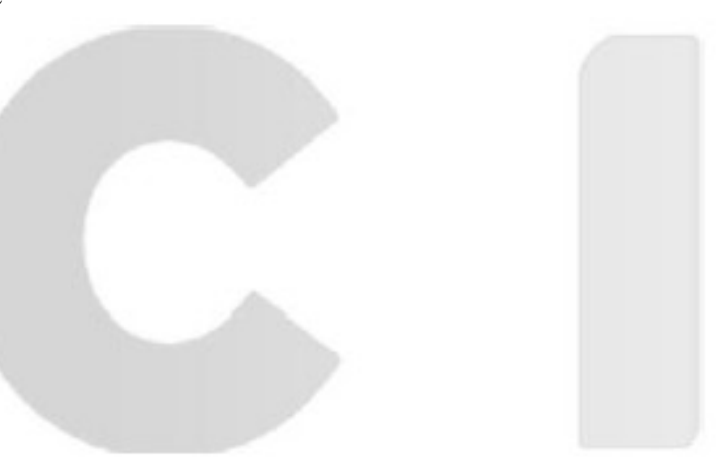


\section{References}

Aguilera, R., \& Dencker, J. (2004). The Role of Human Resource Management in Cross- Border Mergers and Acquisitions. International Journal of Human Resource Management, 15(8), 1355-1370.

Ahammad, M., Tarba, S., Liu, Y., \& Glaister, K. (2016). Knowledge transfer and cross-border acquisition performance: The impact of cultural distance and employee retention. International Business Review, 25(1), 65-75.

Ahammad, M., \& Glaister, K. (2011). The double-edge effect of cultural distance on cross-border acquisition performance. European Journal of International Management, 5(4), 327-345.

Akanni, M., \& Ahammad, M. (2015). National Cultural Distance and International Acquisition Performance. Journal of Economics. Business and Management, 3(2), 183-187.

Anh, P., Baughn, C., Hang, N., \& Neupert, K. (2006). Knowledge acquisition from foreign parents in international joint ventures: An empirical study in Vietnam. International Business Review, 15(5), 463-487.

Armstrong, S., \& Mahmud, A. (2008). Experiential Learning and the Acquisition of Managerial Tacit Knowledge. Academy of Management Learning \& Education, 7(2), 189-208.

Birkinshaw, J., Bresman, H., \& Nobel, R. (2010). Knowledge transfer in international acquisitions: A retrospective. Journal of International Business Studies, 41(1), 21-26.

Bjorkman, I., Stahl, G., \& Vaara, E. (2007). Cultural differences and capability transfer in cross-border acquisitions: The mediating roles of capability complementarity, absorptive capacity, and social integration. Journal of International Business
Studies, 38(4), 658-672.

Bresman, H., Birkinshaw, J., \& Nobel, R. (2010). Knowledge transfer in international acquisitions. Journal of International Business Studies, 41(1), 5-20.

Castro, C., \& Neira, E. (2005). Knowledge transfer: Analysis of three Internet acquisitions. International Journal of Human Resource Management, 16(1), 120-135.

Chatterjee, S., Lubatkin, M., Schweiger, D., \& Weber, Y. (1992). Cultural differences and shareholder value in related mergers: Linking equity and human capital. Strategic Management Journal, 13(5), 319-334.

Child, J., Falkner, D., \& Pitkethly, R. (2001). The Management of International Acquisitions. Oxford: Oxford University Press.

Churchill Jr., G. (1979). A Paradigm for Developing Better Measures of Marketing constructs. Journal of Marketing Research, 16(1), 64-73.

Cohen, W., \& Levinthal, D. (1990). Absorptive capacity: A new perspective on learning and innovation. Administrative Science Quarterly, 35(1), 128-152.

Datta, D., \& Puia, G. (1995). Cross-border acquisition: An examination of the influence of relatedness and cultural fit on shareholder value creation in US acquiring firms. Management International Review, 35(4), 337-359.

Evangelista, F., \& Hau, L. (2009). Organizational context and knowledge acquisition in IJVs: An empirical study. Journal of World Business, 44(1), 63-73.

Frost, T., Birkinshaw, J., \& Ensign, P. (2002). Centers of excellence in multinational corporations. Strategic Management Journal, 23(11), 997-1018.

Gupta, A., \& Govindarajan, V. (2000). Knowledge flows within multinational corporations. Strategic Management Journal, 21(4), 473-496. 
Hair, J., Black, B., Babin, B., \& Anderson, R. (1998). Multivariate Data Analysis. 5th ed. New york: PrenticeHall.

Hammami, H., Amara, N., \& Landry, R. (2013). Organizational climate and its influence on brokers' knowledge transfer activities: A structural equation modelling. International Journal of Information Management, 33(1), 105-118.

Hamel, G. (1991). Competition for competence and inter-partner learning within international strategic alliances. Strategic Management Journal, 12(4), 83-103.

Hayward, M. (2002). When do firm learn from their acquisition experiences? evidence from 1990-1995. Strategic Management Journal, 23(1), 21-39.

Henderson, R., \& Cockburn, I. (1994). Measuring competence? Exploring firm effects in pharmaceutical research. Strategic Management Journal, 15(S1), 63-84.

Hennart, J., \& Larino, J. (1998). The impact of culture on the strategy of multinational enterprises: Does national origin affect ownership decisions. Journal of International Business Studies, 29(3), 515-538.

Hitt, M., Harrison, J., Ireland, R., \& Best, A. (1998). Attributes of successful and unsuccessful acquisitions of US firms. British Journal of Management, 9(2), 91-114.

Hofstede, G. (1980). Culture's consequences: International differences in work-related values. Beverly Hills; London: Sage Publication.

Inkpen, A., \& Crossan, M. (1996). Believing is seeing: Joint ventures and organizational learning. Journal of Management Studies, 32(5), 595-618.

Kogut B., and Zander, U. (1992). Knowledge of the fi $\mathrm{rm}$, combinative capabilities, and the replication of technology. Organization Science, 3(3),
383-397.

Krug, J., Wright, P., \& H. Kroll (2014). Top management turnover following mergers and acquisitions: Solid research to date but much to be learned. Academy of Management Perspectives, 28(2), 147-163.

Laursen, K., \& Salter, A. (2006). Open for innovation: the role of openness in explaining innovation performance among UK manufacturing firms. Strategic Management Journal, 27(2), 131-150.

Lyles, M., \& Salk, J. (2007). Knowledge acquisition from foreign parents in international joint ventures: an empirical examination in the Hungarian context. Journal of International Business Studies, 38(1), 3-18.

Easterby-Smith, M., Lyles, M., \& Tsang, E. (2008). Inter-Organizational Knowledge Transfer: Current Themes and Future Prospects. Journal of Management Studies, 45(4), 677-690.

Morosini, P., Shane, S., \& Singh, H. (1998). National cultural distance and cross-border acquisition performance. Journal of International Business Studies, 29(1), 137-158.

Mowery, D., Oxley, J., \& Silverman, B. (1996). Strategic alliances and inter-firm knowledge transfer. Strategic Management Journal, 17(Winter), 77-91.

Nonaka, I. (1994). A dynamic theory of organizational knowledge creation. Organization Science, 5(1), 14-37.

Nunnally, C. (1978). Psychometric Theory. 2nd ed. New york: McGraw-Hill.

Olie, R. (1994). Shades of culture and institutions in international mergers. Organization Science, 15(3), 381-405.

Pak. Y., \& Park, Y. (2004). Global ownership strategy of Japanese multinational enterprises: A test of internalization theory. Management International 
Review, 44(1), 3-21.

Park, B., Giroud, A., \& Glaister, K. (2009). Acquisition of managerial knowledge from foreign parents: evidence from Korean joint ventures. Asia Pacific Business Review, 15(4), 527-545.

Pérez-Nordtvedt, L., Kedia, D., Datta, D., \& Rasheed, A. (2008). Effectiveness and Efficiency of Cross-Border Knowledge Transfer: An Empirical Examination. Journal of Management Studies 45(4), 714-744.

Ranft, A., \& Lord, M. (2002). Acquiring New Technologies and Capabilities: A Grounded Model of Acquisition Implementation. Organization Science, 13(4), 420-441.

Reus, T., \& Lamont, B. (2009). The double-edged sword of cultural distance in international acquisitions. Journal of International Business Studies, 40(8), 1298-1316.

Sarala, R. (2010). The impact of cultural differences and acculturation factors on post-acquisition conflict. Scandinavian Journal of Management, 26(1), 38-56.

Sarala, R., \& Vaara, E. (2010). Cultural differences, convergence and crossvergence as explanations of knowledge transfer in international acquisitions. Journal of International Business Studies, 41(8), 1365-1390.

Shenkar, O. (2001). Cultural distance revisited: Towards a more rigorous conceptualization and measurement of cultural differences. Journal of International Business Studies, 32(3), 519-535.

Shan, W., Walker, G., \& Kogut, B. (1994). Interfirm cooperation and start-up innovation in the biotechnology industry. Strategic Management Journal, 15(5), 387-394.

Schneider, B., Salvaggio, A., \& Subirats, M. (2002). Climate strength: A new direction for climate research. Journal of Applied Psychology, 7(2), 220-229.

Simonin, B. (1999). Transfer of marketing know-how in international strategic alliance: An empirical investigation of the role and antecedents of knowledge ambiguity. Journal of International Business Studies, 30(3), 463-490.

Slangen, A. (2006). National cultural distance and initial foreign acquisition performance: The moderating integration. Journal of World Business, 41(2), 161-170.

Szulanski, G. (1996). Exploring internal stickiness: Impediments to the transfer of best practice within the firm. Strategic Management Journal, 17(S2), 27-43.

Teerikangas, S., \& Very, P. (2006). The culture-performance relationship in M\&A: From Yes/No to how. British Journal of Management, 17(S1), S31-S48.

Tsang, E. (2008). Transferring Knowledge to Acquisition Joint Ventures: An Organizational Unlearning Perspective. Management Learning, 39(1), 5-20.

Uhlenbruck, K. (2004). Developing acquired foreign subsidiaries: The experiences of MNEs in transition economies. Journal of International Business Studies, 35(2), 109-123.

Vaara, E., Sarala, R., Stahl, G., \& Bjorkman, I. (2012). The impact of organizational and national cultural differences on social conflict and knowledge transfer in international acquisition. Journal of Management Studies, 49(1), 1-27.

Vaara, E. (2003). Post acquisition integration as sensemaking: Glimpses of ambiguity, confusion, hypocrisy and politicization. Journal of Management Studies, 40(4), 859-894.

Vasilaki, A., \& O’Regan, N. (2008). Enhancing post-acquisition organizational performance: The role of the Top Management Team. Team Performance 
Management, 14(3/4), 134-145

Vermeulen, F., \& Barkema, H. (2001). Learning through acquisitions. Academy of Management Journal, 44(3), 457-476.

Walsh, J. (1988). Top management turnover following mergers and acquisitions. Strategic Management Journal, 9(2), 173-183.

Weber, R., \& Camerer, R. (2003). Cultural conflict and merger failure: An experimental approach. Management Science, 49(4), 400-415.

Weber, Y., Tarba, S., \& Rozen Barchar, Z. (2012). The effect of cultural clash on national mergers in the high tech industry. World Review of Entrepreneurship, Management and Sustainable Development, 8(1), 103-118.

Weber, Y., Shenkar, O., \& Raveh, A. (1996). National and corporate culture fit in mergers/acquisitions: An explorative study. Management Science, 42(8), 1212-1227.

Wijk, R., Jansen, J., \& Lyles, M. (2008). Inter- and Intra-Organizational Knowledge Transfer: A Meta-Analytic Review and Assessment of its Antecedents and Consequences. Journal of Management Studies, 45(4), 830-853.

$\mathrm{Wu}, \mathrm{A}$. (2016). The mediating roles of governance mechanisms and knowledge transfer on the relationship between specific investments and cooperative innovation performance. Technology Analysis \& Strategic Management, 28(2), 217-230.

Zander, U., \& Zander, L. (2010). Opening the grey box: Social communities, knowledge and culture in acquisition. Journal of International Business Studies, 41(1), 27-37.

Zou, H., \& Ghauri, P. (2008). Learning through international acquisitions: The process of knowledge acquisition in China. Management International Review, 48(2), 207-226.

\section{저자사항(author(s) note)}

\section{Joohan Ryoo(류주한)}

·Jhryoo@hanyang.ac.kr

- Associate professor, Division of International Studies, Hanyang University, Seoul, Korea

- Author's research focuses on international global strategies including mergers and acquisitions, strategic alliances, foreign market entry and localization.

- 한양대학교 국제학부 부교수 


\section{Appendix 1}

Summary of literatures on the knowledge transfer in international acquisition (Selective)

\begin{tabular}{|c|c|c|c|c|c|}
\hline Author(s) & Sample & $\begin{array}{l}\text { Dependent } \\
\text { variable }\end{array}$ & $\begin{array}{l}\text { Independent } \\
\text { variables }\end{array}$ & $\begin{array}{l}\text { Control } \\
\text { variables }\end{array}$ & Major findings \\
\hline Bresman et al.(2010) & $\begin{array}{l}31 \text { individuals and } \\
71 \text { questionnaire }\end{array}$ & Knowledge transfer & $\begin{array}{l}\text { Communications } \\
\text { Visit/meeting } \\
\text { Articulability } \\
\text { Time elapse }\end{array}$ & Firm size & $\begin{array}{l}\text { At the beginning, knowledge transfer was } \\
\text { made in hierarchial manner, but later in more } \\
\text { reciprocal process. }\end{array}$ \\
\hline Castro \& Neira (2005) & 3 Internet & Knowledge transfer & $\begin{array}{l}\text { Autonomy, } \\
\text { Retention, } \\
\text { Interaction, } \\
\text { Cultural similarity }\end{array}$ & & $\begin{array}{l}\text { The degree of autonomy is critical to the } \\
\text { knowledge transfer, while retention and } \\
\text { cultural similarity are not conclusive. }\end{array}$ \\
\hline $\begin{array}{l}\text { Gupta \& Govindarajan } \\
\text { (2000) }\end{array}$ & 374 US subsidiaries & Knowledge flow & \begin{tabular}{|l|} 
Knowledge stock \\
Motivational \\
disposition \\
Transmission channel
\end{tabular} & $\begin{array}{l}\text { Industry type } \\
\text { Revenue } \\
\text { Regions }\end{array}$ & $\begin{array}{l}\text { Knowledge stock of recipients impacts } \\
\text { the knowledge flow }\end{array}$ \\
\hline $\begin{array}{l}\text { Laursen \& Salter } \\
\text { (2006) }\end{array}$ & 6,287 CIS survey & $\begin{array}{l}\text { Innovation } \\
\text { performance }\end{array}$ & $\begin{array}{l}\text { Openness of a firm } \\
\text { External search depth }\end{array}$ & $\begin{array}{l}\text { R\&D intensity } \\
\text { R\&D expenditure }\end{array}$ & $\begin{array}{l}\text { Using external source helps firms achieve } \\
\text { innovation substantially. However,. searching } \\
\text { widely and deeply is culvilinearly related to } \\
\text { performance }\end{array}$ \\
\hline Pak \& park (2004) & $\begin{array}{l}195 \text { international } \\
\text { acquisitions }\end{array}$ & $\begin{array}{l}\text { Knowledge transfer } \\
\text { in new product } \\
\text { development } \\
\text { acquisition }\end{array}$ & $\begin{array}{l}\text { Relation-specific } \\
\text { condition, } \\
\text { Knowledge-specific } \\
\text { condition, }\end{array}$ & $\begin{array}{l}\text { degree of equity- } \\
\text { ownership }\end{array}$ & $\begin{array}{l}\text { Social interaction, knowledge attribute, } \\
\text { absorptive capacity are required in. } \\
\text { knowledge transfer }\end{array}$ \\
\hline Ranft \& Lord (2002) & $\begin{array}{l}7 \text { cases of UK } \\
\text { manufacturing firms }\end{array}$ & Capability transfer & $\begin{array}{l}\text { Nature of knowledge, } \\
\text { Management practice, } \\
\text { Acquisition content }\end{array}$ & $\begin{array}{l}\text { Speed, } \\
\text { Communication, } \\
\text { Authority, }\end{array}$ & $\begin{array}{l}\text { Identified factors were found critical in } \\
\text { transferring knowledge and capability during } \\
\text { the acquisition process. }\end{array}$ \\
\hline $\begin{array}{l}\text { Perez-Nordtvedt et al. } \\
(2008)\end{array}$ & 102 US firms & $\begin{array}{l}\text { Effectiveness \& eff } \\
\text {-ectiveness of } \\
\text { knowledge transfer } \\
\text { in international } \\
\text { market }\end{array}$ & $\begin{array}{l}\text { Knowledge charac- } \\
\text { teristics, } \\
\text { Recipient intents, } \\
\text { Source of attraction, } \\
\text { Relationship quality }\end{array}$ & $\begin{array}{l}\text { Relationship type, } \\
\text { Knowledge type, } \\
\text { Internationalization } \\
\text { level. } \\
\text { industry type }\end{array}$ & $\begin{array}{l}\text { All positively related to the international } \\
\text { knowledge transfer and relationship and } \\
\text { relationship quality plays the moderate } \\
\text { role }\end{array}$ \\
\hline Zou \& Ghauri (2008) & 4 cases researches & $\begin{array}{l}\text { Knowledge acqui- } \\
\text { sition }\end{array}$ & $\begin{array}{l}\text { Learning process, } \\
\text { Network capacity }\end{array}$ & & $\begin{array}{l}\text { Knowledge transfer involves three stages } \\
\text { assessment, sharing and assimilation. } \\
\text { Dual management and communication are } \\
\text { essential in this process. }\end{array}$ \\
\hline
\end{tabular}




\section{Appendix 2}

Summary of literatures on the organizational and national cultures in international acquisition (Selective)

\begin{tabular}{|c|c|c|c|c|c|}
\hline Author(s) & Sample & $\begin{array}{l}\text { Dependent } \\
\text { variable }\end{array}$ & $\begin{array}{l}\text { Independent } \\
\text { variables }\end{array}$ & $\begin{array}{l}\text { Control } \\
\text { variables }\end{array}$ & Major findings \\
\hline $\begin{array}{l}\text { Akanni \& Ahammad } \\
\text { (2015) }\end{array}$ & $\begin{array}{l}1,733 \text { cross-border } \\
\text { M\&A deals }\end{array}$ & $\begin{array}{l}\text { International } \\
\text { acquisition } \\
\text { performance }\end{array}$ & $\begin{array}{l}\text { Power distance, } \\
\text { In group collectivism, } \\
\text { Uncertainty avoidance }\end{array}$ & & $\begin{array}{l}\text { In order to succeed, management styles and } \\
\text { communication strategies need to be adapted } \\
\text { to suit the target firms culture. Trust must be } \\
\text { developed amongst all members in order to } \\
\text { reduce any resistance to change. }\end{array}$ \\
\hline Ahammad et al. (2016) & 118 US firms & $\begin{array}{l}\text { International } \\
\text { acquisition } \\
\text { performance }\end{array}$ & Cultural distance & $\begin{array}{l}\text { Market share, } \\
\text { Sales, } \\
\text { Stock price }\end{array}$ & $\begin{array}{l}\text { Cultural distance impedes the understanding } \\
\text { of the key capabilities traferred but enhance } \\
\text { understandability and communication }\end{array}$ \\
\hline Chatterjee et al.,(1992) & Merger performance & & & & $\begin{array}{l}\text { Strong inverse relationship between } \\
\text { perceptions of cultural differences and } \\
\text { shareholder gains, after controlling for } \\
\text { perceptions of the buying firm's tolerance for } \\
\text { multiculturalism and the relative size of the } \\
\text { merging firms. }\end{array}$ \\
\hline Olie (1994) & $\begin{array}{l}3 \text { cases of } \\
\text { Dutch-German } \\
\text { mergers }\end{array}$ & $\begin{array}{l}\text { Merger integration } \\
\text { process }\end{array}$ & $\begin{array}{l}\text { Compatibility, } \\
\text { Consolidation, } \\
\text { Integrity, } \\
\text { Relational nature }\end{array}$ & $\begin{array}{l}\text { Size, } \\
\text { Industry, } \\
\text { Time elapse, } \\
\text { Integration effort, } \\
\text { Organizational } \\
\text { autonomy }\end{array}$ & $\begin{array}{l}\text { Leadership, approproate structure, } \\
\text { motivational compatibility are important } \\
\text { facilitators in merger process }\end{array}$ \\
\hline Sarala \& Vaara (2010) & $\begin{array}{l}44 \text { Finish acquisition } \\
\text { cases }\end{array}$ & Knowledge transfer & $\begin{array}{l}\text { Organizational cultural } \\
\text { difference, National } \\
\text { cultural difference, } \\
\text { Cultural converncece, } \\
\text { Cultural cross vergence }\end{array}$ & $\begin{array}{l}\text { Industry type, } \\
\text { Year, } \\
\text { Net sales }\end{array}$ & $\begin{array}{l}\text { National cultural differences, organizational } \\
\text { cultural convergence and crossvergence have } \\
\text { a significant positive impact on knowledge } \\
\text { transfer. In particular, convergence and } \\
\text { crossvergence moderate the impact of national } \\
\text { cultural differences on knowledge transfer }\end{array}$ \\
\hline Morosini et al. (1998) & $\begin{array}{l}52 \text { international } \\
\text { acquisition } \\
(1987-1992)\end{array}$ & $\begin{array}{l}\text { International } \\
\text { acquisition } \\
\text { performance }\end{array}$ & $\begin{array}{l}\text { Cultural distance, } \\
\text { Uncertainty avoidance, } \\
\text { PMI strategy, } \\
\text { Relatedness }\end{array}$ & $\begin{array}{l}\text { Host contry } \\
\text { experience, } \\
\text { Acquisition size, } \\
\text { Demand growth }\end{array}$ & $\begin{array}{l}\text { positive association between national cultural } \\
\text { distance and cross-border acquisition } \\
\text { performance is found }\end{array}$ \\
\hline Slangen (2006) & $\begin{array}{l}119 \text { Dutch } \\
\text { acquisitions }\end{array}$ & $\begin{array}{l}\text { Acquisition } \\
\text { performance }\end{array}$ & $\begin{array}{l}\text { Cultural distance, } \\
\text { Integration, }\end{array}$ & Relative size & $\begin{array}{l}\text { Large national cultural differences reduce } \\
\text { international acquisition performance. }\end{array}$ \\
\hline $\begin{array}{l}\text { Weber \& Camerer } \\
\text { (2003) }\end{array}$ & $\begin{array}{l}\text { Experimental } \\
\text { study }\end{array}$ & $\begin{array}{l}\text { Merger } \\
\text { failure }\end{array}$ & $\begin{array}{l}\text { Organizational } \\
\text { culture }\end{array}$ & & $\begin{array}{l}\text { Experimental study reveals that many mergers } \\
\text { are doomed to be failed due to cultural and } \\
\text { coordinated failure. }\end{array}$ \\
\hline Vaara (2003) & $\begin{array}{l}\text { Cases of } 3 \text { Swedish } \\
\text { companies }\end{array}$ & $\begin{array}{l}\text { Post acquisition } \\
\text { integration progress }\end{array}$ & $\begin{array}{l}\text { Cultural confusion in } \\
\text { social interaction and } \\
\text { communication; } \\
\text { organizational } \\
\text { hypocrisy and the } \\
\text { politicization }\end{array}$ & & $\begin{array}{l}\text { Slow integrration progress occurs due to } \\
\text { inherent ambiguity, cultural confusion in } \\
\text { social interaction and communication, } \\
\text { organizational hypocrisy and the politicization } \\
\text { of integration issues. }\end{array}$ \\
\hline
\end{tabular}



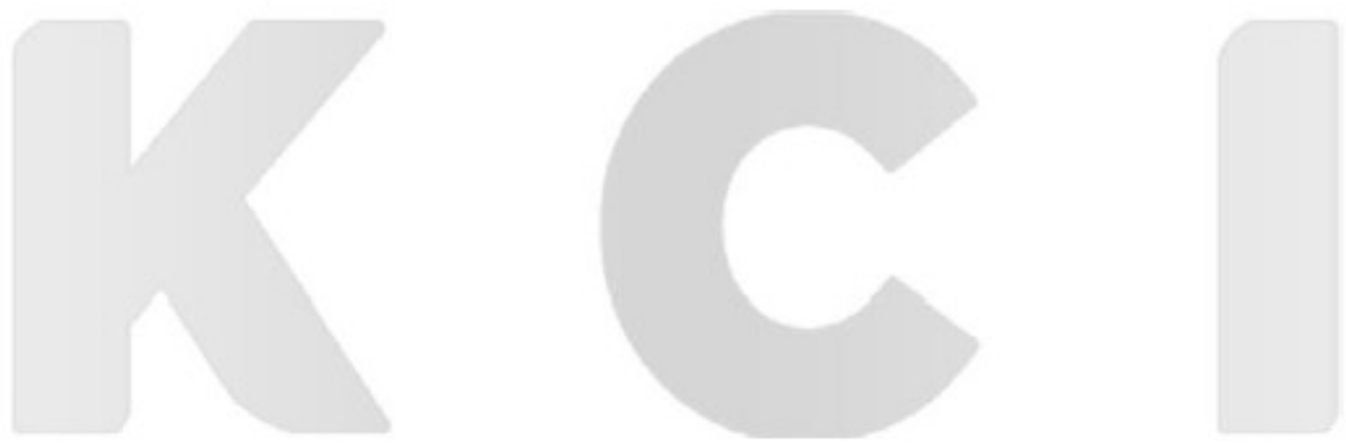